\title{
Readers as overhearers and texts as objects: joint attention in reading communities
}

\author{
Vera Tobin *
}

\begin{abstract}
Resumo
Models of language that emphasize the interactive dimension of meaning construction tend to talk about published texts such as the novel as an arena of language use in which writers and readers occupy the positions of speaker and addressee. This paper argues that readers of published texts function in many ways more like overhearers than addressees. It uses tools from Conversation Analysis and Mental Spaces Theory to examine several case study interactions, drawn from the Michigan Corpus of Spoken Academic English and videotaped data from gesture research, as well as illustrative examples from literary history. The overhearer model that emerges suggests that the interactions between different readers of the same text are a more important locus of collaboration in literary discourse than is typically assumed, and shows that joint activities between readers also often exclude authors in interesting and important ways.
\end{abstract}

Keywords: Interaction. Literature. Overhearers. Addressees. Joint attention. Mental spaces

\section{Introduction}

Conversation analysis, gesture studies, linguistic anthropology, and other investigations of the interactive dimensions of language use have increasingly demonstrated just how many aspects of meaning and linguistic structure in conversation are inextricable from the situated, interactive occasion of their production - that, in the words of Goodwin, sentences "emerge as the products of a process of interaction between speaker and hearer and that they mutually construct the turn at talk.”. (GOODWIN, 1975, p. 98) These valuable insights into the role of collaboration in the construction of meaning run into some trouble, however, when applied to the production, dissemination, and interpretation of written, published texts.

* Case Western Reserve University, Cleveland, Ohio, USA. 
Writing and reading can be, and often are, understood as a sort of conversation between author and reader. However, the insights into the role of interactivity in language that make this model so useful for theorists also render it problematic. We know that in person, people coordinate their communicative activities in real time and get immediate feedback about whether they have succeeded or failed in their communicative intentions. Participants in face to face conversation also typically have access to a host of visual cues that help them to keep track of the immediate attentions of their interlocutors, and this knowledge provides important information about what they can consider part of the common ground underlying a conversation. In a situation where readers and writers are unknown to one another, how can they be said to interact? Should we conclude that literary texts (for example) involve only displaced, imaginary interactions, or no interactions at all? Or do the dynamics of immediate, direct interaction have real bearing on the experience of producing and consuming these texts?

This paper argues that readers of published texts function in many ways more like overhearers than like addressees, and that the interactions between different readers of the same text are perhaps a more important locus of collaboration in the process of meaning construction involved in reading literature. These joint activities between readers also often exclude authors in interesting and important ways.

\section{Language use as a collaborative process}

In conversation, sentences and conversational turns are constructed not in isolation, but as the products of an interactive process between speaker and hearer. Elements such as pauses, repairs, and restarts, as well as linguistic and nonlinguistic displays of agreement, confusion, or lack of interest all contribute to the construction of coherent streams of talk. (GOODWIN, 1986; 1980).

Models of language use that emphasize this interactional factor tend to treat texts as communicative acts that are very much like conversation, in which authors play the part of speakers and readers play the part of hearers. In this account, authors and readers have to do some extra imaginative work that ordinary conversations may not require, but they are still in some fundamental sense interacting with one another. For instance, Clark (1996) suggests that the authors and readers of 
fictional texts "jointly pretend" that the communicative acts depicted by a text are really taking place. Bruce (1981) writes of a "social interaction between author and reader" in which readers understand authors to be depicting a communicative interaction between an implied author and an implied reader, which itself depicts an interaction between a narrator and a narratee.

There are some obvious limitations to this analogy. For example, the production and comprehension of literary texts lack most of the concrete opportunities for direct interaction that are available in face-to-face communication. In person, people coordinate their communicative activities in real time and get immediate feedback about whether they have succeeded or failed in their communicative intentions. The readers of published works generally have no way of confirming what they have understood or asking for clarification, and authors have no way of modifying their contributions on the fly in response to the reactions of their readers. While cognitive psychologists, linguists in the field of pragmatics, and scholars working on conversation analysis are generally very comfortable saying that understanding an utterance requires a hearer to recognize or at least formulate some notion of a speaker's communicative intentions, literary critics are often exceedingly wary of appeals to authorial intention or any kind of fixed, knowable interpretation of a text.

At the same time, there are many excellent reasons to believe that the same kinds of conceptual work that underlie language use in conversation are crucially involved in the production and interpretation of novels, screenplays, essays, and any number of other uses of language in "nonbasic" settings (CLARK; BRENNAN, 1991). Many influential works in cognitive linguistics and related fields (e.g. LAKOFF; JOHNSON, 1980; CHAFE, 1994; GIBBS, 1994; TURNER, 1996) have argued convincingly that the language of literature and the language of everyday conversation are expressions of the same cognitive mechanisms. All of these settings of language use involve human beings with the same social and cognitive capacities and limitations, using a hugely overlapping set of linguistic resources: lexical, semantic, grammatical, and pragmatic. A published story or advertisement can use indexical expressions, generate implicatures, and trigger presuppositions. It can do rhetorical work and perform a variety of speech acts: it can exhort, request, perhaps even promise.

Furthermore, it is very common for authors and readers to act as if reading a novel has a great deal in common with being on the hearing end of a conversation, 
and as if writing one has a great deal in common with speaking to someone. Readers use what they know - or think they know - about an author in generating inferences and making judgments about what a text "means" (see, for example, NOLEN, 1995 and GIBBS, 1999). Similarly, readers often draw or attempt to draw explicit inferences about authorial intent as they read - does the author mean for this to be ironic? Is this supposed to be funny?

\section{Defining some terms}

This paper has proceeded so far as if the main salient difference between the sort of language use exemplified by face-to-face conversations and the sort that is exemplified by the novel is that the latter is written. The primary distinguishing feature of this kind of discourse would seem, so far, to be that it has authors and readers, rather than speakers and hearers. The questions to be answered seem to be: Is reading really like being on the receiving end of a conversation? Is writing really like talking to someone?

This is not an uncommon way of defining the problem. Dixon and Bortolussi, for example, criticize the application of conversational models to text processing by arguing that there are crucial ways in "many forms of written discourse" are "unlike oral communication" and like one another. (2001, p. 1). Chafe writes of "the desituatedness of writing" and observes that "[t]he writing situation is itself unreal in its detachment from the co-presence and interaction which are normal for conversational language". (CHAFE, 1994, p.224).

However, I want to pause here to point out that while many of the discourse types at issue here are indeed written rather than spoken, the sheer fact that they are writing is not the most important thing they have in common. The questions above have unstated assumptions. They might be more explicitly phrased: Is reading published texts really like being on the receiving end of a conversation? Is writing for publication really like talking to someone?

It is worth noting that people can be engaged unambiguously in direct, conversational interaction in written media. For example, my neighbor and I can scribble notes to one another during a colloquium. When we do this, we are clearly addressing our written utterances to one another. We can also see one another, and share a visible and audible, jointly accessible shared environment. We can 
immediately provide both linguistic and non-linguistic indications of whether we are attending to and understanding what the other person is writing.

Conversations conducted via instant messaging, another written arena of conversational language use, usually lack some of these features: typically the participants are not visible to one another and do not share a common perceptual ground. They are, however, known to one another in the same way that any ordinary participants in a conversation would be. They may be strangers, but they understand themselves and one another to be directing their utterances to a specific individual or individuals. They can also respond to one another immediately. They can interrupt, after a fashion; they can ask for clarification, take up or reject proposed construals, and modify what they say quickly and flexibly in response to one another's contributions.

Private letters, meanwhile, lack the conversational qualities of co-presence and simultaneity. Nonetheless, if all goes well, and the letter is delivered and read as intended, most analysts would agree that the writer and addressee are engaged in a real, if distant, interaction with one another. Anyone who intercepted the letter before it reached its intended destination, or who happened across the letter after the fact, is plainly a bystander to the original interaction.

The discourse types that I have been calling "texts", by contrast, generally lack both immediacy and participant transparency. When an article is written for publication, its author has no idea who, in particular, will be reading the magazine in which it is published; nor does she have a sense beyond an educated guess about when or in what contexts it will be read - and this aspect of the discourse situation is something that the author understands to be the case as she is writing. ${ }^{1}$ The same is true for any text produced for public media: comic strips, films, radio broadcasts, or novels. I will continue to use the terms text, author, and reader to describe this kind of public discourse types, their producers, and their audiences. However, I will freely include examples from discourse genres other than written narratives, and will exclude directly conversational genres, even if they are conducted in writing.

1 There are several interesting edge cases. Durable works originally created for private settings may be later disseminated to a wider audience, or as was common in early modern manuscript culture (as well as in many contemporary online communities), works may be created for semi-public distribution within a relatively well-defined reading community. 


\section{Common objections to the conversation model for texts}

A variety of objections are frequently raised to the idea that reading may be usefully understood as a collaborative, or conversational, activity. These fall into two broad categories: complications that arise from the separation of readers and authors in space and time, and complications that arise from the difference between the ostensible speaker of a literary text and the real, historical author or authors of that text.

\section{Authors and readers are not physically co-present}

Authors are not present during the comprehension of a text, nor are readers present during a text's creation. There is a long tradition in literary criticism, based fundamentally on this observation, to avoid considerations of authors' intentions as much as possible. W. K. Wimsatt and Monroe Beardsley $(1942,1954)$ coined the term "intentional fallacy" to dismiss critical readings of literary texts that rely on external evidence about what an author "meant" when writing them. Poststructuralist theorists (e.g. BARTHES, 1977) have argued more radically that the very concept of the author as a means of understanding literature has lost its validity.

Concretely, there are several ways in which this lack of co-presence makes for significant disanalogies with basic conversational interaction: The discourse situation of the published text means that author and reader have no shared perceptual and referential common ground in which the discourse is situated. They have no access to the usual physical cues regarding their interlocutor's interest, comprehension, and visual attention. Most importantly, perhaps, they have no opportunity to engage in the immediate feedback loop that is so crucial to conversation.

Readers cannot ask authors for clarification; they cannot confirm their understanding or contribute new ideas. Authors cannot modify their contributions on the fly in response to an individual reader's responses. What's more, there is no shared interaction between a reader and an author leading up to the production and comprehension of a narrative. Narratives in conversation normally emerge out of 
the ordinary give and take of conversational turn taking; they are locally occasioned (JEFFERSON, 1978), their progress is shaped by audience contributions over the course of many turns (GOODWIN, 1986), and conversation generally continues after the narrative is complete. There is rarely any comparable preliminary and consequent interaction between the author and the reader of a text.

Pascual (2002) points out that all sorts of discourse invoke varieties of "fictive interaction", conceptualizations that are underwritten by a particular and pervasive conceptual blend (FAUCONNIER; TURNER, 2002) in which a situation is imaginatively reconstructed in terms of a canonical conversation frame (FILLMORE, 1982). The result is discourse that invokes or relies on an imagined interactional structure that diverges significantly from the observable communicative situation. Certainly both authors and readers understand what they are doing at least in part by means of this fictive interaction blend. As we will see, however, many of the concrete interactive experiences that characterize face-toface communication do literally, or factively (TALMY, 1996) take place as part of the interpretation of texts - but these take place between readers, rather than between readers and authors.

\section{Who Is Speaking?}

Dixon and Bortolussi (2001), among others, have argued that the text communication model is rendered fatally problematic by the fact that the speaker or narrator of a literary text is not the author. Readers typically have even less access to the intentions of an author than the mere lack of co-presence would suggest, because the real person who wrote a given text is not speaking as herself, and readers are often in a very poor position to tease apart the author from the speaker. This complication is especially obvious in the case of texts with overt narrators (BOOTH, 1961) who clearly diverge from the beliefs, feelings, and biographical details of the author. However, it is also importantly true even in cases such as expository texts in which the narrator appears to be identical with the author, or narratorless and dramatic texts, such as narrative films, radio plays, comics, and other kinds of sequential art.

Where one is available, readers often focus more on the narrator than on the real or implied author of a text. Indeed, they will often make unsupported or 
faulty assumptions about the author based on information provided by a narrator or focalizing character. For example, readers tend to assume that the author of passages in which perceptual information is attributed to a male focalizer is also male, and also assume that passages in which perceptual information is attributed to a female character were written by a woman (DIXON; BORTOLUSSI, 2001).

Graesser, Bowers, Olde, and Pomeroy (1999) suggest that even third-person narrators are generally not nearly as accessible in memory as first-person narrators and other characters. Perhaps this is why readers often conflate the expressed beliefs of narrators and even nonnarrator characters with those of the author or implied author of a text. Take, for example, the assertions in (1) and (2):

(1) Robert Frost said good fences make good neighbors. He never knew John Ames and Perry Brooks. (BATTIATA, 2005)

(2) Robert Frost said that good fences make good neighbours. I would say that good hedges do much the same thing. (ROBERTSON, 2003)

As it happens, Robert Frost said no such thing; even these sophisticated consumers of texts are conflating Frost, the author of "Mending Wall" (1915), with a character from that poem. The character himself is only parroting an already well-established adage, and the speaker, or narrator, of the poem is quoting the neighbor in order to criticize him:

There where it is we do not need the wall:

$\mathrm{He}$ is all pine and I am apple orchard.

My apple trees will never get across

And eat the cones under his pines, I tell him.

He only says, "Good fences make good neighbors".

It is not clear, however, that these mistakes defeat the general claim that readers take the author of a text to be their interlocutor, and that they infer an author's intentions as they interpret a text. Readers who are familiar with the conventions of Western-style fictional narratives do understand that the author of a text created its narrator, and can draw inferences about the narrator based on what they know or assume about the author or implied author. For example, knowing 
something about the character, publication history, and contemporary social norms of Jonathan Swift can help us to recognize the irony in "A Modest Proposal", and we can seek out more specific information about his expressed beliefs in trying to sort out what is and is not meant to be ironic in Gulliver's Travels. Readers also commonly wonder whether inconsistencies in a text are deliberate or accidental, which similarly requires appeal to the real author's communicative intentions.

Where the divergence between the implied or apparent author of a text and the real author becomes more problematic for the text-as-communication model is in the pervasive assumption of unitary authorship. In order to read the narrative as a narrative, readers must act as if the communicative intentions behind the text are coherent. Yet a single work is often not - perhaps even usually not - a unified performance of just one person's communicative intentions. For one thing, any extended narrative may be the work of several years. It is hard to imagine that an author's intentions don't shift over the course of that writing, and the order in which various parts were written is not at all visible to most readers.

While a published text generally gives the appearance of unitary authorship, there is almost always a great deal of collaboration and revision involved that is not visible to the audience. Editors intervene, pre-publication readers make comments and suggestions, publishers request title changes, and so on. Films and television, of course, are the product of many different people's communicative intentions: screenwriters, producers, directors, cinematographers, actors, and editors. If ordinary readers cannot and do not sort out what elements of a text were contributed by what real agent and when, surely they are not interacting in any meaningful way with those agents, fictively or otherwise.

\section{Readers as overhearers}

Part of the solution to these difficulties may be to remember that even in ordinary conversation, not all hearers are addressees. Readers have several points in common with certain kinds of overhearers. Authors and readers alike behave in many ways as if readers were ratified bystanders, for whose benefit the ostensible speech acts of a text are displayed.

Hearers come in a number of different varieties: one may be an addressee, a deliberate or accidental eavesdropper whom the speaker is not aware of, or a 
bystander whose access to a piece of talk is perceivable by those who are doing the talking. Bystanders can be ratified participants in an encounter (cf. GOFFMAN 1981, p. 131-137) as when a professor answers one student's question during a twelve-person seminar, or not, as when diners at different tables in a restaurant expect one another to engage in the polite fiction that they cannot hear one another. The degree to which speakers are aware of their bystander listeners can vary, as can the degree to which they take their needs into account.

Gerrig proposes that readers do indeed correspond to one particular kind of non-addressee hearer commonly involved in ordinary face-to-face conversation. In his account, both authors and readers typically "behave as if readers are sideparticipants" - not overhearers - to the discourse of a narrative text, and "in that role, authors intend readers to be genuinely informed by narrative utterances". (GERRIG, 1993, p. 110) While overhearers have to try to make sense of utterances that were produced with no attempt to ensure that they share the speaker's perspective, Gerrig argues, authors conceptualize their readers as intended, ratified participants in the narrative discourse, whose needs must be taken into account.

The side-participant account has the merit of explaining some common ways in which narrative texts tend to defy verisimilitude. For example, we often see a character or narrator using nominals that correspond to a much lower degree of accessibility (ARIEL, 1990) than one would expect given the supposed state of shared knowledge between the represented speaker and her ostensible addressee. Striking examples of this phenomenon are common in serial narratives, in which a mere handful of represented conversational turns may be published over the course of many days or months. The first panels of daily comic strips are full of them. Example (3) is from an installment of the soap-opera strip Mary Worth:

(3) Dawn: My father wouldn't approve of my dating Drew! He wouldn't be able to overlook the age difference!

Mary: $\quad$ Give Wilbur more credit, Dawn!

Stilted though this dialogue may be, it does some useful work anticipating the needs of many of the strip's likely readers. Mary Worth is a daily comic with a wide variety of secondary characters. Readers, even those who frequently read the comic strip but have not been following the current story arc, may be unfamiliar with who Dawn's father is, despite Dawn and Mary's knowledge. The 
side-participant hypothesis explains this sort of usage nicely.

At the same time, there are important ways in which readers are more like overhearers of a text's author than they are like co-participants of any sort. Overhearers have access to the utterances that make up a stretch of discourse, but lack the opportunity to participate in the negotiation of meaning and exchange of clarifications. This missed opportunity has real effects on their ability to understand what speakers are saying, even when they can hear every word and see every gesture. Because they have no chance to collaborate in establishing a shared perspective, they are slower to comprehend a stream of discourse than direct participants in that discourse (SCHOBER and CLARK, 1989). Readers of published texts are in much the same position: no matter how thoroughly an author's communicative intentions are directed towards generating particular interpretations for a text's real readers, readers are at a major disadvantage with comparison to any co-present interlocutor.

\section{Overhearers as Interlocutors}

\section{Collaboration in Conversation}

When speakers and hearers interact, they engage in what Clark calls joint construal: "For each signal, the speaker and addressees try to create a joint construal of what the speaker is to be taken to mean by it." (CLARK, 1996, p. 212) Sometimes this happens smoothly and without incident, but it always requires actions on the part of both speaker and hearer. In Clark's terminology, the speaker proposes a joint project and the hearer takes it up. The uptake response provides evidence that the hearer understood the speaker's utterance, and also of the way that the hearer is construing that utterance. For example, if Ann says to Bill, "Eat some spinach", each of the responses in (4) would suggest a different construal of that utterance:

(4) a. Yes, ma'am! [an order]

b. Thanks, I'm fine. [an offer]

c. What a good idea! [an advisory] 
If the displayed construal matches Ann's original intentions, she can proceed on that basis, which allows Bill to understand that this construal is now jointly held between them. If the construal doesn't match, she can correct it ('I'm not asking you, I'm telling you!") or leave Bill's construal unchanged and revise her own intentions about what she should be taken as doing.

Construals can be also revised or corrected over the course of multiple conversational turns, as illustrated by the following example, taken from an exchange on an Internet discussion board (Unfogged.com 2006):

\section{(5) Revised construal}

1BL: To the extent that your project here is instead just to emphasize that I, personally, am a bad person (because your contracts professor and I took some of the same classes in college), I disagree with you. At least in this respect.

2LB: No, no, I think you're a bad person for entirely different reasons.

3BL: Such as?

4LB: Crap, I'm such a wimp. I was considering pasting a "(just kidding! :-)!!!)" on the end of that, and decided not to, but now I have to. No, I don't think you're a bad person at all, not in the slightest. I just saw a straight line and took it.

Here the revised construals pertain to the affective content of the speaker's meaning. LB's utterance in 2 seems to be construed by BL in 3 as an insult; in 4, LB adopts that construal and apologizes, proposing a clarifying revision to her earlier remark.

References, too, can be worked out over the course of several conversational turns, as in the following example, from the Michigan Corpus of Spoken Academic English (MICASE OFC150MU042):

(6) Clarifying reference

S3: yeah yeah that's (right) and, remember like Lana Lane or some or Lana something

S1: Lois Lane? [suggestion]

S3: no no it's Lois Lane but no there's another girl Lana right? [partial rejection, partial acceptance]

S7: yeah that takes over the paper [confirmation and continuation]

S3: yeah [acceptance] 


\section{Collaboration in text Interpretation}

Authors and readers are not in a position to engage with one another in the kinds of exchanges found in (5) and (6). However, co-present readers of the same text certainly are, and this is exactly what they often do, putting the text into the stream of talk and requesting or suggesting glosses, fresh interpretations, and alternate construals as they go, using all the usual resources of face-to-face communication.

Narayan (2012) provides an excellent example of how co-present interpreters of texts make use of the resources afforded by face-to-face interaction, including gestures, posture, and gaze management. In this study, pairs of subjects sat facing one another, positioned so that one participant could see panels from various comics projected on a screen, while the other could not. The task of the first participant (here, P1) was to describe each panel until both participants agreed that the second participant (P2) understood what was being depicted.

In this example, $\mathrm{P} 1$ has difficulty coming to the canonical explanation of what the panel depicts - a car pulling across traffic to nab a parking spot, while the car's driver triumphs and the driver of the car he has cut off honks his horn in anger. P1 has repeatedly described the car as "pulling out of a spot", and once as "tryna pull out into the road". P2 is able to recognize that there is something wrong with P1's interpretation, and over four and a half minutes and several dozen turns of conversation, the two work to revise P1's original construal, arriving eventually at a mutual understanding of the image that matches the canonical one.

\section{(7) Revised construal}

P1: The car parked behind the bug is so hard to see, could even be a taxicab, it's just a yellow car, um...

It's hard to see because the word honk

Um

Is basically over the top of it.

P2: It's interesting that it says SCORE, maybe what it means is he actually got the spot, as opposed to...

looks at P1

P1: Ohhh! Yeah! 
Here $\mathrm{P} 1$ and $\mathrm{P} 2$ have generated much the same kind of revised construal seen in (5). P2 uses his gaze to check P2's comprehension, prompting her to confirm that she agrees and will adopt his revised construal. While they have no opportunity to interact meaningfully with the creator of the original text, their interpretation of the text is highly interactive, and relies crucially on cues from one another's gestures and gaze as well as from their talk. They stand as overhearers with respect to the creator of the text, but active co-participants with respect to one another.

We see something similar in the following example, from an undergraduate classroom discussion on Philip Roth's novel The Ghost Writer. Here, a student, S4, combines quotation of the text with a variety of conversational resources to signal her own comprehension and confusion to the instructor, S1. For clarity, I have used italics to mark the words and phrases that the speakers are reading from the novel. Otherwise I have retained the transcription conventions of the original, in which punctuation indicates prosodic rather than grammatical features.

\section{Clarifying references (MICASE LES300SU103)}

S1: um, can you start too late mother. page one-oh-six? and, read loud enough so that everybody can, hear you.

S4: too late mother, didn't you read the ten questions from, Nathan Zuckerman? dear, i did possess a copy, and the letter too the big three mama um, strikers?

S1: mm, they're those these are two Nazi um, officials. (actually) [S4: and i, ] they were both, they both were involved in Nazi propaganda.

S4: and your son what about um, the judge's um, humility? where is his modesty? uh he only e- he only meant what happened, to the Jews in Europe not in Newark. we are, no- we are not the wretched of, Belsen who is Belsen?

S1: Belsen uh Bergen-Belsen is a concentration camp and this is the camp where Anne Frank died.

Observe that S4's reading of the text here functions as a great deal more than simple quotation. S1 does not have to guess where S4 would benefit from her greater knowledge of the background information necessary to make sense of various references in this passage. Instead, she customizes her contributions and clarifications based on S4's performance. S4 uses intonation, pauses, restarts, and inserted requests for clarification to bring the advantages of face-to-face 
communication to bear on her understanding of the text; Roth's text is being used as a discursive element reframed in her own voice, allowing her to signal what she does and does not understand.

\section{Authors as overhearers}

Finally, groups of readers can and do form eccentric, insular interpretive communities, generating bodies of interpretive work that may well be wholly or largely impenetrable to other readers and even to the original author of the source text. These groups constitute discourse communities in the sense proposed by Swales (1990): They have common public goals, they have established mechanisms for communication and information exchange among members of the group, they make use of community-specific genres and specialized terminology, and their interactions require a high general level of relevant expertise.

One example of this kind of inter-reader group is the "Sherlockian" community of fans of Arthur Conan Doyle's stories about Sherlock Holmes, which I have written about in some detail in Tobin (2006). These readers write scholarly articles, squibs, and entire books under the conceit that Holmes and Watson were real people. The writers of Sherlockian compositions also typically serve as the primary audience for one another's contributions to this body of work. To the uninitiated, the resulting productions can be difficult to distinguish from sincere confusion over the fictional status of the stories. Indeed, Arthur Conan Doyle himself found the pastime both distasteful and mystifying. (LELLENBERG; STASHOWER; FOLEY, 2007).

Today's popular culture supports a multitude of similarly idiosyncratic reading communities for all kinds of novels, television shows, comic books, and other texts, producing enormous quantities of collaborative interpretations and alternative "replottings" (GERRIG, 1993). It is common to find the authors of the source texts expressing a certain amount of bewilderment about these discourses, even if they are ultimately flattered by the attention and sympathetic with their readers' desire to find a creative outlet. J. K. Rowling, author of the wildly popular Harry Potter series, spoke of this experience in an interview: 
For a long time I never looked. People used to say to me, "Do you ever look at the fan sites or see what people have said online?" I was truthful; I said I didn't. Then one bored afternoon, I googled "Harry Potter." Oh... my... God. I had NO idea.

What we see happening in these examples are situations in which authors are neither part of nor entirely oblivious to the kinds of extended, highly participatory, interpretive discourses taking place among communities of their readers. In this way, authors can find themselves transformed into the overhearers of their own readers' interpretive conversations.

\section{Conclusion}

Theoretical analyses of discourse processing often assume that texts in general and published fictional narratives in particular should be thought of as a form of interaction between the author and the reader, in which writers and readers occupy the positions of speaker and addressee. While these analyses are right to look for interaction in the literary event, they are largely looking for it in the wrong place. In functional terms, readers act primarily as overhearers, rather than as addressees (even side-addressees), of authors' textual utterances. In this role, they engage in side conversations with other readers, treating the texts as the objects of their joint attention. These interactions between readers draw on many of the concrete resources of immediate conversation that authors and their readers cannot share. Indeed, authors who encounter the product of these interactions often find themselves inhabiting the role of overhearers - even eavesdroppers - themselves. 


\title{
Leitores como ouvintes casuais e textos como objeto: atenção compartilhada em comunidades de leitura
}

\begin{abstract}
Resumo
Os modelos da linguagem que dão ênfase à dimensão interativa da construção do significado centram-se normalmente em textos publicados, como o romance, enquanto terreno do uso linguístico em que escritores e leitores assumem o lugar de falantes e destinatários. Este estudo propõe que os leitores de textos publicados funcionam antes como ouvintes casuais mais do que como destinatários. Com base nas ferramentas da Análise de Conversação e da Teoria dos Espaços Mentais, este trabalho examina várias interações retiradas do Corpus do Michigan de Inglês Acadêmico Americano e ainda dados gravados da investigação de gestos, bem como exemplos ilustrativos da história da literatura. O modelo de ouvintes casuais que aqui se apresenta sugere que as interações entre diferentes leitores do mesmo texto são um local mais importante de colaboração no discurso literário do que tipicamente se supõe e mostra, ainda, que as atividades compartilhadas entre os leitores também excluem normalmente os autores, de formas interessantes e importantes.

Palavras-chave: Interação. Literatura. Ouvintes Casuais. Destinatários. Atenção conjunta. Espaços mentais.
\end{abstract}

References

ARANDA, Natalie. The Pros and Cons of Vinyl Fencing. EzineArticles. Disponível em: <http://ezinearticles.com/?The-Pros-and-Cons-of-VinylFencing\&id=434398> . Acesso em: $1^{\circ}$ ago. 2007.

ARIEL, Mira. Accessing noun phrase antecedents. London: Routledge, 1990.

BARTHES, Roland. The Death of the Author. In: BARTHES, Roland. Image, music, text. Tradução de Stephen Heath. New York: Hill and Wang, 1977. p. 14247.

BATTIATA, Mary. Blood Feud. Washington Post. 22 May 2005. W8.

BOOTH, Wayne C. The Rhetoric of Fiction. Chicago: University of Chicago Press, 1961. 
BRUCE, Bertram C. A Social Interaction Model of Reading. Discourse processes, v. 4, p. 273-311, 1981.

CHAFE, Wallace L. Discourse, consciousness, and time: The Flow and Displacement of Conscious Experience in Speaking and Writing. Chicago: University of Chicago Press, 1994.

CLARK, Herbert H. Using language. Cambridge: Cambridge University Press, 1996.

CLARK, Herbert H.; BRENNAN, Susan A. Grounding in Communication. In: RESNICK, Lauren B.; LEVINE, John M.; TEASLEY, Stephanie D. (Ed.). Perspectives on socially shared cognition. Washington: APA Books, 1991. p. $127-49$.

DIXON, Peter; BORTOLUSSI, Marisa. Text Is Not Communication: A Challenge to a Common Assumption. Discourse processes, v. 31, p. 1-25, 2001.

FAUCONNIER, Gilles; TURNER, Mark. The way we think. New York: Basic Books, 2002.

FILLMORE, Charles J. Frame Semantics. In: THE LINGUISTIC SOCIETY OF KOREA (Ed.). Linguistics in the morning calm. Seoul: Hanshin, 1982. p. 11137.

FROST, Robert. Mending Wall. In: FROST, Robert. North of Boston. New York: Dover Reprint, 28, 1915.

GERRIG, Richard J. Experiencing narrative worlds. New Haven: Yale University Press, 1993.

GIBBS, Raymond W. The poetics of mind: Figurative Thought, Language, and Understanding. New York: Cambridge University Press, 1994.

GIBBS, Raymond W. Intentions in the experience of meaning. New York: Cambridge University Press, 1999.

GOFFMAN, Erving. Footing. In: GOFFMAN, Erving. Forms of talk. Philadelphia: University of Pennsylvania Press, 1981. p. 124-59.

GOODWIN, Charles. The Interactive Construction of a Sentence in Natural Conversation. Everyday language: Studies in Ethnomethodology. Editrado por George Psathas. New York: Irvington Publishers, 1979. p. 97-121.

GOODWIN, Charles. Restarts, Pauses, and the Achievement of a State of Mutual Gaze at Turn-Beginning. Sociological inquiry, v. 50, p. 272-302, 1980. 
GOODWIN, Charles. Audience Diversity, Participation and Interpretation. Text, v. 6, p. 283-316, 1986.

GRAESSER, Arthur C.; BOWERS, Cheryl; OLDE, Brent; POMEROY, Victoria. Who said What? Source Memory for Narrator and Character Agents in Literary Short Stories. Journal of educational psychology, v. 91, p. 284-300, 1999.

JEFFERSON, Gail. Sequential Aspects of Storytelling in Conversation. In: SCHENKEIN, Jim. Studies in the organization of conversational interaction. New York: Academic Press, 1978. p. 219-48.

LAKOFF, George; JOHNSON, Mark. Metaphors we live by. Chicago: University of Chicago Press, 1980.

Leaky Cauldron. 2000. Transcript: Joanne K. Rowling at Radio City in "An Evening with Harry, Carrie and Garp". Disponível em: <http://www.the-leakycauldron.org/page/event-reports/jkrnycnight1>. Acesso em: $1^{\circ}$ ago. 2007.

LELLENBERG, Jon; STASHOWER, Daniel; FOLEY, Charles. Arthur Conan Doyle: A Life in Letters. New York: Penguin Press, 2007.

NARAYAN, Shweta. Maybe what it means is that he actually got the spot: Physical and cognitive viewpoint in a gesture study. In: DANCYGIER, Barbara and Sweetser, Eve (Ed.). Viewpoint in language: A Multimodal Perspective. Cambridge: Cambridge University Press, 2012.

NOLEN, Susan Bobbitt. Effects of Visible Author on Statistics Texts. Journal of educational psychology, v. 87, p. 47-65, 1995.

PASCUAL, Esther. Imaginary trialogues: Conceptual Blending and Fictive Interaction in Criminal Courts. Utrecht: LOT, 2002. Dissertation Series, n. 68.

ROBERTSON, S. Good hedges make good neighbors. The gazette. 9 Aug. 2003. SCHOBER, Michael F.; CLARK, Herbert H. 1989. Understanding by Addressees and Overhearers. Cognitive psychology, v. 21, p. 211-232, 1989.

SIMPSON, Rita C.; BRIGGS, Sarah L.; OVENS, Janine; SWALES, John M. The michigan corpus of academic spoken english. Ann Arbor, MI: The Regents of the University of Michigan, 2002.

Unfogged.com. Is Economics Science, Or Are Economists More Like 19th Century Natural Philosophers? Messages posted to <http://www.unfogged.com/ archives/comments_5794.html>. Acesso em 16 nov. 2006. 
TALMY, Leonard. Fictive Motion in Language and "Ception". In: BLOOM, Paul; PETERSON, Mary A.; NADEL, Lynn; GARRETT, Merrill F. (Ed.). Language and space. Cambridge, MA: MIT Press, 1996. p. 211-276.

TOBIN, Vera. Ways of Reading Sherlock Holmes: The Entrenchment of Discourse Blends. Language and literature, v. 15, p. 73-90, 2006.

TURNER, Mark. The Literary Mind. New York: Oxford University Press, 1996.

WIMSATT, William Kurtz; BEARDSLEY, Monroe C. Intention. In: Dictionary of world literature. Editado por Joseph T. Shipley. New York: Philosophical Library, 1942. p. 326-9.

WIMSATT, William Kurtz; BEARDSLEY, Monroe C. The Intentional Fallacy. The verbal icon: Studies in the Meaning of Poetry. Lexington: University of Kentucky Press, 1954. p. 3-18. 